\title{
Enhanced Internalization of Nanoparticles Following Ionizing Radiation Leads to Mitotic Catastrophe in MG-63 Human Osteosarcoma Cells
}

\author{
Roxana Cristina Popescu ${ }^{1,2}$, Mihai Straticiuc ${ }^{3}$, Cosmin Mustăciosu ${ }^{1,2}$, Mihaela Temelie ${ }^{1}$, \\ Roxana Trușcă ${ }^{4}$, Bogdan Ștefan Vasile ${ }^{4}\left(\mathbb{D}\right.$, Adina Boldeiu ${ }^{5}$, Dragoş Mirea ${ }^{3}$, \\ Radu Florin Andrei ${ }^{3,6}$, Constantin Cenușă ${ }^{7}$, Laurenţiu Mogoantă ${ }^{8}$, George Dan Mogoșanu ${ }^{9}$, \\ Ecaterina Andronescu ${ }^{2}$, Mihai Radu ${ }^{1}\left(\mathbb{D}\right.$, Marlon R. Veldwijk ${ }^{10, *}$ and Diana Iulia Savu ${ }^{1, *} \mathbb{1}$
}

1 Department of Life and Environmental Physics, "Horia Hulubei” National Insitute of Physics and Nuclear Engineering (IFIN-HH), 30 Reactorului Street, 077125 Magurele, Romania; roxana.popescu@nipne.ro (R.C.P.); cosmin@nipne.ro (C.M.); mihaela.temelie@nipne.ro (M.T.); mradu@nipne.ro (M.R.)

2 Department of Science and Engineering of Oxide Materials and Nanomaterials, "Politehnica" University of Bucharest (UPB), 1-7 Polizu Street, 011061 Bucharest, Romania; ecaterina.andronescu@upb.ro

3 Department of Applied Nuclear Physics, "Horia Hulubei” National Insitute of Physics and Nuclear Engineering (IFIN-HH), 30 Reactorului Street, 077125 Magurele, Romania; mstrat@nipne.ro (M.S.); dragos.mirea@nipne.ro (D.M.); radu.andrei@nipne.ro (R.F.A.)

4 Department of Science and Engineering of Oxide Materials and Nanomaterials, National Research Center for Micro and Nanomaterials, "Politehnica" University of Bucharest (UPB), 313 Splaiul Independenţei, 060042 Bucharest, Romania; truscaroxana@yahoo.com (R.T.); bogdan.vasile@upb.ro (B.S.V.)

5 Laboratory of Nanobiotechnology, National Institute for Research and Development in Microtechnologies (IMT), 12A Erou Iancu Nicolae Street, 077190 Bucharest, Romania; adina.bragaru@imt.ro

6 Department of Physics, Applied Science Faculty, "Politehnica” University of Bucharest (UPB), 303 Splaiul Independentei, 060042 Bucharest, Romania

7 Radioisotopes and Radiation Metrology Department, "Horia Hulubei" National Insitute of Physics and Nuclear Engineering (IFIN-HH), 30 Reactorului Street, 077125 Magurele, Romania; constantin.cenusa@nipne.ro

8 Research Center for Microscopic Morphology and Immunology, University of Medicine and Pharmacy of Craiova (UMFCV), 2 Petru Rareș Street, 200349 Craiova, Romania; editor@rjme.ro

9 Department of Pharmacognosy \& Phytotherapy, Faculty of Pharmacy, University of Medicine and Pharmacy of Craiova (UMFCV), 2 Petru Rareș Street, 200349 Craiova, Romania; mogosanu2006@yahoo.com

10 Department of Radiation Oncology, Universitätsmedizin Mannheim (UMM), Medical Faculty Mannheim, University of Heidelberg, 68167 Mannheim, Germany

* Correspondence: Marlon.Veldwijk@medma.uni-heidelberg.de (M.R.V.); dsavu@nipne.ro (D.I.S.); Tel.: +49-621-383-3750 (M.R.V.); +40-214-046-134 (D.I.S.)

Received: 30 August 2020; Accepted: 28 September 2020; Published: 30 September 2020

\begin{abstract}
This study aims to investigate whether ionizing radiation combined with doxorubicin-conjugated iron oxide nanoparticles (NP-DOX) improves the internalization and cytotoxic effects of the nano-carrier-mediated drug delivery in MG-63 human osteosarcoma cells. NP-DOX was designed and synthesized using the co-precipitation method. Highly stable and crystalline nanoparticles conjugated with DOX were internalized in MG-63 cells through macropinocytosis and located in the perinuclear area. Higher nanoparticles internalization in MG-63 cells previously exposed to $1 \mathrm{~Gy}$ X-rays was correlated with an early accumulation of cells in $\mathrm{G}_{2} / \mathrm{M}$, starting at $12 \mathrm{~h}$ after treatment. After $48 \mathrm{~h}$, the application of the combined treatment led to higher cytotoxic effects compared to the individual treatment, with a reduction in the metabolic capacity and unrepaired DNA breaks, whilst a low percent of arrested cells, contributing to the commitment of mitotic catastrophe. NP-DOX showed hemocompatibility and no systemic cytotoxicity, nor histopathological alteration of the main organs.
\end{abstract}


Keywords: MG-63 osteosarcoma; ionizing radiation; iron oxide nanoparticles; doxorubicin; combined antitumor treatment

\section{Introduction}

Osteosarcoma is a very aggressive common primary bone tumor affecting predominantly children, teenagers and young adults aged 10-30 years, accounting for $5 \%$ of all pediatric malignancies [1].

Current standard management of osteosarcoma consists in multi-modal treatment including surgery, multi-agent chemotherapy (including doxorubicin (DOX)) and radiotherapy, yielding to $60 \%$ of the 5 -year survival rate, while less than $20 \%$ of patients with metastatic disease or relapsed osteosarcoma reach a long-term survival [2,3]. However, none of these conventional treatments are effective in combating the tumor progression, and continuing high rates of limb amputation, pulmonary metastasis and normal tissue toxicity remain unresolved issues [4]. Thus, new effective and safe strategies, in particular targeted therapies, are clearly required [4].

In this context, nanoparticle-based drug delivery systems can be designed to pass biological barriers and to target cancerous cells, where they enter and accumulate to reach the drug therapeutic target, while, in the meantime, reducing its systemic toxicity $[5,6]$. Iron oxide nanoparticles proved to be suitable for such applications due to their biocompatibility for healthy tissues [7] and magnetic targeting ability [8,9]. Moreover, there are several FDA (Food and Drug Administration)-approved systems based on iron oxide nanoparticles for clinical use in cancer treatment through magnetic hyperthermia [10].

The efficient delivery and retaining of nanoparticles in tumor cells are the most important steps towards clinical translation, with many studies referring to targeting a certain state of the tumor cell, such as $\mathrm{G}_{2} / \mathrm{M}$ cell cycle arrest, which would imply a higher internalizing efficiency [11-13]. Previous reports proved that both nanoparticles and radiotherapy can induce cell cycle arrest in $\mathrm{G}_{2} / \mathrm{M}$ phase [14-16]. Moreover, it was shown that therapeutic doses of irradiation can improve the uptake of nanoparticles in various cell lines [17], however, this range of irradiation can also lead to side effects. By reducing the ionizing radiation dose, the side effects are also reduced, while the $\mathrm{G}_{2} / \mathrm{M}$ delay can still be induced with the chance of enhancing nanoparticles uptake. Starting from these considerations, we hypothesize that medium doses (1 Gy) of ionizing radiation, followed by a novel nano-system, doxorubicin-conjugated iron oxide nanoparticles (NP-DOX) administration, would enhance the nanoparticles internalization and consequently, would increase the cytotoxic effects of nano-carrier-mediated drug delivery in aggressive tumor cell models, such as the MG-63 human osteosarcoma. Doxorubicin was selected as a chemotherapeutic model due to its fluorescence property, which confers a convenient traceability to the nano-system.

To test our hypothesis, mechanistic investigation concerning the effect of ionizing radiation on the internalization and cytotoxicity of NP-DOX have been performed in a MG-63 human osteosarcoma cell model. We synthesized the nanoparticles (as described in Popescu et al. [18]) and then characterized them using relevant physico-chemical methods (Supplementary Materials Sections S1.1 and S2.1). In vitro testing on MG-63 cells revealed information on the internalization, cyto- and geno-toxicity of NP-DOX and have been used to select the experimental conditions, concentrations and observation time points for the investigations we report here (Supplementary Materials Section S2.2).

The effect of combined ionizing radiation with nanoparticles (1 Gy X-rays applied prior to NP-DOX treatment) was investigated through the metabolic and proliferator behavior of osteosarcoma cells (3-(4,5-dimethylthiazol-2-yl)-2,5-diphenyltetrazolium bromide (MTT), trypan blue and colony formation assays), but also through the genotoxic response (comet and micronuclei assays). Quantitative measurements of the atomic Fe concentration in the cells were done using Particle-Induced X-ray Emission (PIXE) spectrometry [19]. These evaluations were correlated with cell cycle measurements and the possible cell death mechanisms were determined through morphological investigations. 
For the first time, our results showed that prior ionizing radiation exposure of MG-63 human osteosarcoma cells determined an enhanced internalization of doxorubicin-conjugated nanoparticles, leading to mitotic catastrophe.

\section{Results}

\subsection{Cells' Morphology, Cytoskeleton Evaluation and Doxorubicin-Conjugated Iron Oxide Nanoparticles NP-DOX Internalization}

Scanning electron microscopy (SEM) was used to evaluate the detailed morphology of NP-DOX-treated MG-63 osteosarcoma cells and their interaction with the nanoparticles (Figures 1 and 2). The images acquired for cells exposed to $500 \mathrm{ppm}$ nanoparticles for $24 \mathrm{~h}$ (Figure 1) and 48 h (Figure 2A-F) revealed a severely altered appearance and an increase in total volume, compared to control cells. At $24 \mathrm{~h}$, the whole membrane appeared to be covered with a layer of agglomerated nanoparticles (Figure 1B,C). The entire analyzed surface was coated by a thin organic layer, including nanoparticles, as shown through back scattering acquisition mode (Figure 1D,E). At $48 \mathrm{~h}$ after treatment (Figure 2), less nanoparticle aggregates appeared on the surface of the exposed MG-63 cells (Figure 2B), probably due to internalization, as indicated by images in back scattering mode (Figure 2F). The nanoparticles-treated osteosarcoma cells showed a similarly altered morphology (Figure 2B). Aggregates of NP-DOX directly interacted with the cellular membranes and the elongations of the actin filaments in the extracellular medium, inducing a ruffled aspect (Figure 2C,D). Vesicle-like structures were emphasized on the exterior of the MG-63 cells treated with 500 ppm nanoparticles (Figure 2B-D).
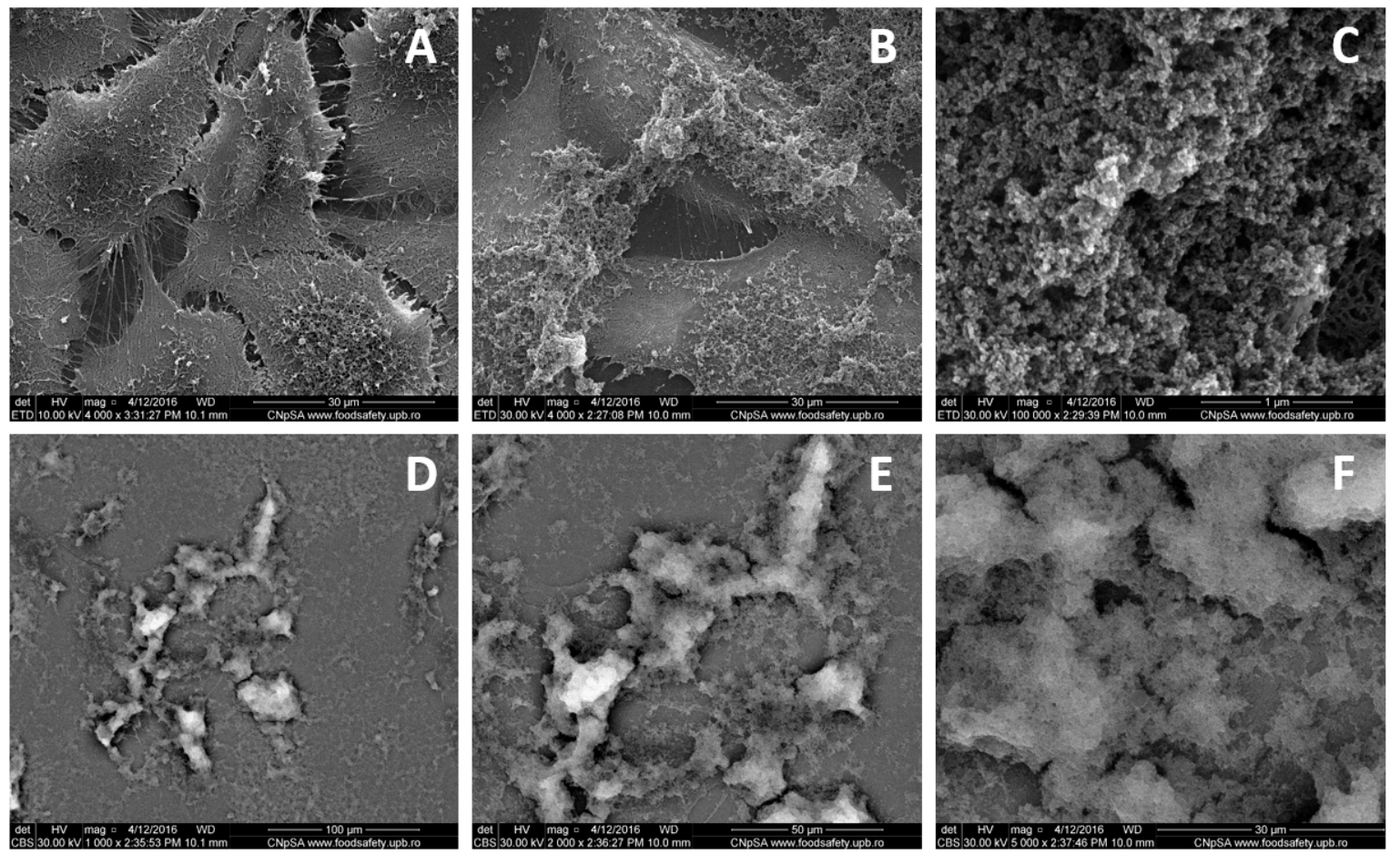

Figure 1. Scanning electron microscopy (SEM) micrographs of MG-63 cells cultured during $24 \mathrm{~h}$ : control (A) and in the presence of 500 ppm doxorubicin-conjugated iron oxide nanoparticles (NP-DOX) (B-F). Information was acquired from secondary electrons (A-E), respectively back scattered electrons (D-F). Images are acquired at different magnifications: $1000 \times($ D), $2000 \times($ E) $, 4000 \times(\mathbf{A}, \mathbf{B}), 5000 \times$ (F) and $100,000 \times(\mathbf{C})$. 


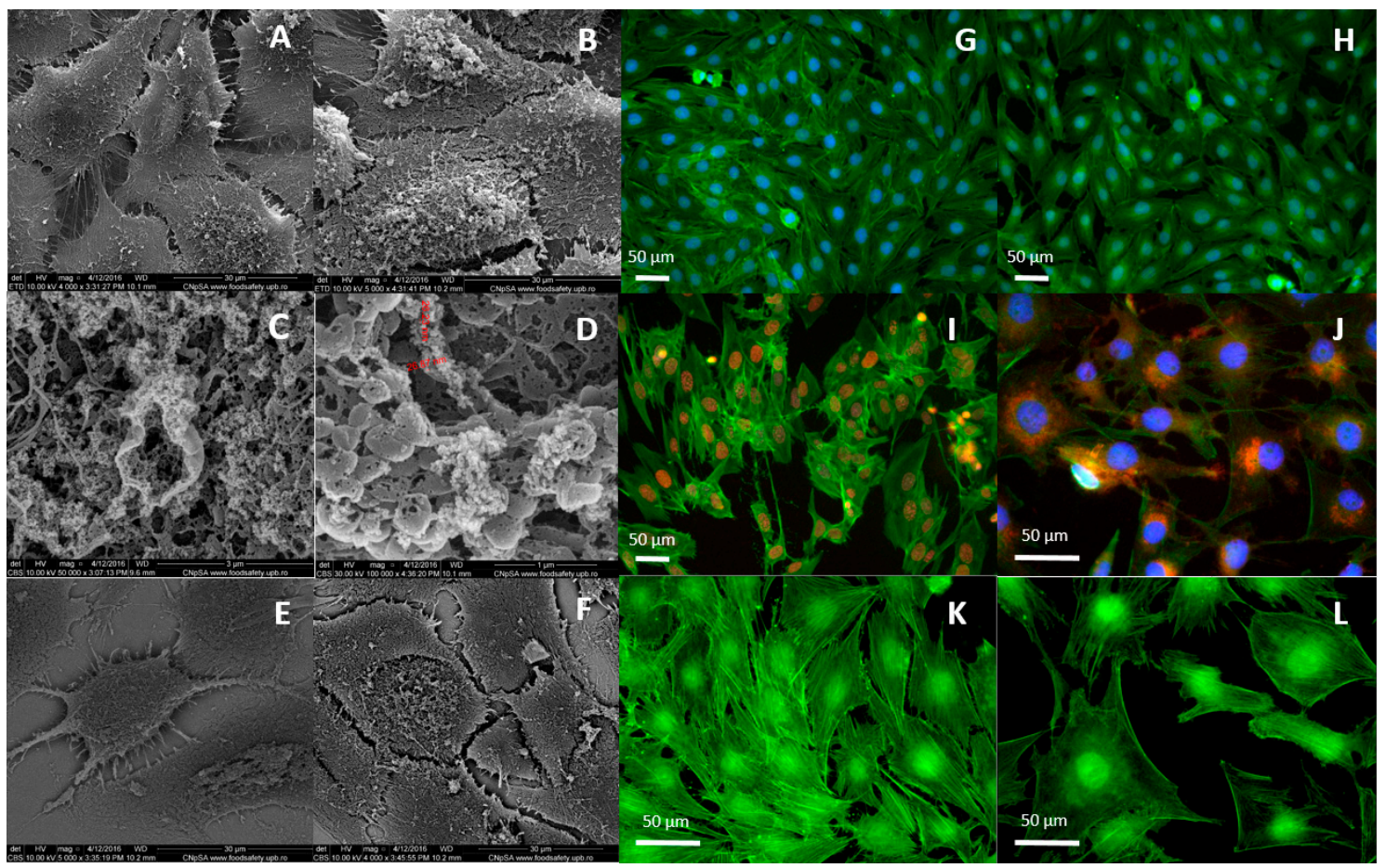

Figure 2. Scanning electron microscopy (SEM) images of MG-63 cells at $48 \mathrm{~h}$ of culture: control (A,E) and in presence of 500 ppm NP-DOX (B-D,F). Information was acquired from secondary electrons (A-D), respectively back scattered electrons $(\mathbf{E}, \mathbf{F})$. Images were acquired at different magnifications: $4000 \times(\mathbf{A}, \mathbf{F})$, $5000 \times(\mathbf{B}, \mathbf{E}), 50,000 \times(\mathbf{C})$ and 100,000 $\times(\mathbf{D})$. Fluorescence microscopy images of cells at $48 \mathrm{~h}$ of culture in presence/absence of nanoparticles: (G) control cells (0 ppm nanoparticles), (H) cells exposed to $500 \mathrm{ppm}$ NP, (I) 2 ppm free DOX (equivalent to DOX concentration in 500 ppm NP-DOX), (J) cells exposed to 500 ppm of bare NP-DOX. Immunohistochemical staining of actin filaments in MG-63 cells exposed during $48 \mathrm{~h}$ to (K) control and (L) 500 ppm NP-DOX. Green: Phalloidin-Fluorescein-5-isothiocyanate (FITC), blue: Hoechst, red: Doxorubicin.

Fluorescence imaging was employed to evaluate the internalization and localization of free DOX, NP and NP-DOX in MG-63 osteosarcoma cells, for the highest equivalent concentrations used in the study, and to detect morphological alterations of the cells by the preceding treatment (Figure 2). Bare NP up to concentrations of $500 \mathrm{ppm}$ did not cause any morphological alterations of the MG-63 cells after $48 \mathrm{~h}$ of exposure (Figure 2H). Treatment with DOX (Figure 2I) and NP-DOX (Figure 2J) in equivalent concentrations induced a modification of their cellular structure and morphology. The osteosarcoma cell volume increased as a result of cells' density decrease (Figure 2I,J). In addition, actin filaments lost their defined fibril structure (Figure 2H,J,L). Free DOX was completely located in the nucleus of the cell (Figure 2I), while DOX-conjugated nanoparticles were situated in the cytoplasm of the cells, in the peri-nuclear area (Figure 2J).

\subsection{Prior Radiation Significantly Enhanced the Cyto- and Geno-Toxic Effect Induced by NP-DOX}

The potential cytotoxic effects of prior ionizing radiation and NP-DOX on MG-63 human osteosarcoma cells were evaluated through metabolic (MTT assay), proliferation (MTT assay and Trypan blue cell counting) and genotoxic investigations (micronucleus and comet assays).

Confluent MG-63 cells were irradiated with $1 \mathrm{~Gy}$, grown for $4 \mathrm{~h}$ and were subsequently exposed to different concentration of NP-DOX in the range of $0-500 \mathrm{ppm}$.

Cells showed a significant reduction in MTT metabolic ability, accentuated for groups that received both treatments (Figure 3A). Thus, cells that underwent 1 Gy X-Ray and NP-DOX exposure, showed a statistically significant reduction in the tetrazolium salt reduction ability in MG-63 cells, dependent on the nanoparticles concentration $(22.64 \% \pm 0.23 \%(p<0.001)$ for $100 \mathrm{ppm}, 35.67 \% \pm 53.67 \%$ 
$(p<0.001)$ for $500 \mathrm{ppm}$ at $24 \mathrm{~h}$ and $26.54 \% \pm 4.4 \%(p<0.001)$ for $100 \mathrm{ppm}, 50.77 \% \pm 54.45 \%(p<0.001)$ for $500 \mathrm{ppm}$ at $48 \mathrm{~h}$, compared to control cells).
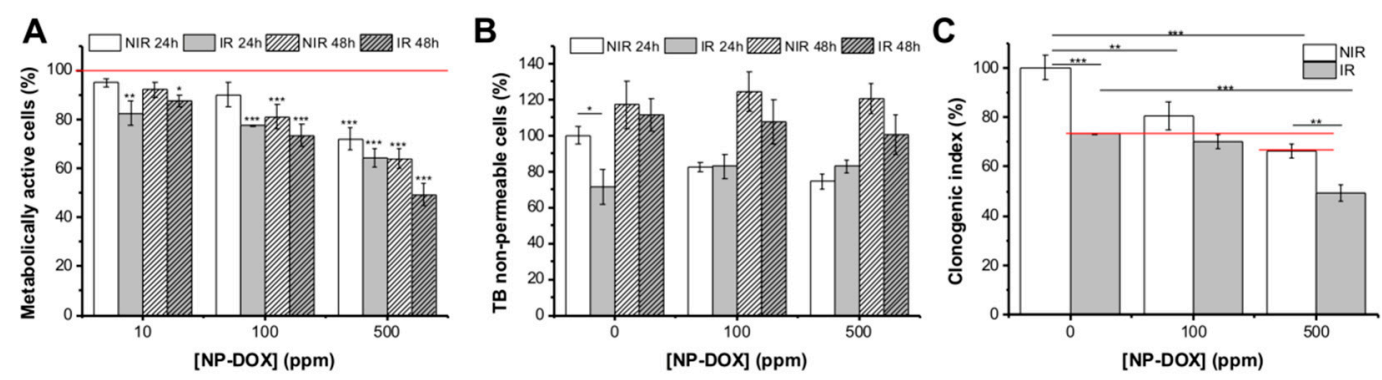

Figure 3. Viability of MG-63 cells exposed to NP-DOX in equivalent concentrations for $24 \mathrm{~h}$ and $48 \mathrm{~h}$. One group of cells was previously exposed to $1 \mathrm{~Gy}$ X-ray (ionizing radiation (IR)) vs. non-irradiated controls (NIR). Evaluation through: (A) metabolic activity measurements, (B) membrane permeabilization, $(\mathbf{C})$ clonogenic survival. Data are presented as mean \pm standard error of the mean (SEM); ${ }^{*} 0.01<p<0.05,{ }^{* *} 0.001<p<0.01,{ }^{* * *} p<0.001$.

Trypan blue assay revealed that the number of viable cells decreased after $24 \mathrm{~h}$ of treatment (compared to seeded cell number), as a result of an initial cytotoxic effect of nanoparticles and/or radiation treatment (Figure 3B). However, measurements after $48 \mathrm{~h}$ of treatment showed that the cells' proliferation was not totally suppressed, as the total viable cell number increased, compared to corresponding samples at $24 \mathrm{~h}$.

Clonogenic assay was done to assess the long-term cytotoxicity of prior radiation treatment (0 Gy, 1 Gy) and NP-DOX (0, 100 and 500 ppm) (Figure 3C). The cell survival decreased with radiation treatment (a reduction of $26.73 \% \pm 0.6 \%$ as compared to untreated cells), with the effect being accentuated by the addition of $500 \mathrm{ppm}$ nanoparticles for $48 \mathrm{~h}$ (total reduction of $50.62 \% \pm 5.8 \%$ as compared to untreated control). NP-DOX alone had an inhibiting effect on the MG-63 survival, dependent on the nanoparticles' concentration. Thus, for $100 \mathrm{ppm}$, the reduction of survival is of $19.51 \%$ $\pm 9.5 \%$, and for $500 \mathrm{ppm}$, the reduction is of $33.59 \% \pm 4.75 \%$, compared to control cells. An important significant effect ( $p<0.001$, respectively $0.001<p<0.01$ ) of ionizing radiation (1 Gy X-rays) and the NP-DOX (500 ppm) treatment on MG-63 clonogenic survival fraction with regard to the single treatment (radiation or nanoparticles) is evident.

The micronuclei measurement was done at 48 and $72 \mathrm{~h}$ of treatment, respectively (Figure $4 \mathrm{~A}$ ). The NP-DOX exposure alone did not show any statistically significant induction of micronuclei in MG-63 cells at any of the time points and concentrations employed. As expected, irradiation alone induced chromosome fragmentation, demonstrated by a statistically significant increase in micronuclei at $48 \mathrm{~h}(p<0.01)$, and at $72 \mathrm{~h}(p<0.05)$. In the1 Gy X-ray + nanoparticles groups, the number of micronuclei increased, compared to control (untreated groups). However, NP-DOX did not determine an additional effect to radiation, but rather the prior exposure to the1 Gy X-ray induced a statistically significant effect compared to groups exposed only to nanoparticles ( $p<0.01$ for $100 \mathrm{ppm}, p<0.001$ for $500 \mathrm{ppm}$ at $48 \mathrm{~h}, p<0.001$ for $100 \mathrm{ppm}$ and $p<0.05$ for $500 \mathrm{ppm}$ at $72 \mathrm{~h}$ ). 

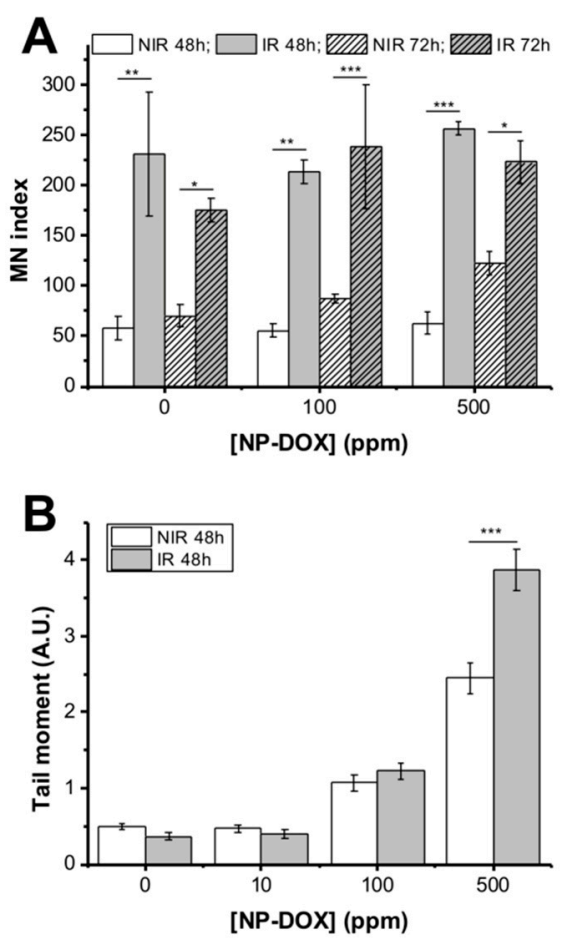

Figure 4. (A) Micronuclei in MG-63 cells, non-irradiated or irradiated with $1 \mathrm{~Gy}$ and exposed to NP-DOX for 48 and $72 \mathrm{~h}$. (B) DNA breaks measured using alkaline comet assay for MG-63 cells either non-irradiated or irradiated with $1 \mathrm{~Gy}$ and exposed for $48 \mathrm{~h}$ to NP-DOX. Data are presented as mean \pm SEM. ${ }^{*} 0.01<p<0.05,{ }^{* *} 0.001<p<0.01,{ }^{* * *} p<0.001$.

However, comet assay showed that the DNA breaks increased with NP-DOX concentration and irradiation at $48 \mathrm{~h}$ (Figure 4B). The exposure of MG-63 cells to $500 \mathrm{ppm}$ nanoparticles after $1 \mathrm{~Gy}$ $\mathrm{X}$-ray determined a 3.01-fold increase in the measured tail intensity $(p<0.001)$, compared to control. In contrast with the micronucleus assay, prior radiation induced a statistically significant effect in DNA breaks compared to NP-DOX alone for 500 ppm groups $(p<0.001)$ with respect to control groups, where radiation alone produced no effect.

\subsection{Radiation Enhanced NP-DOX Internalizing in $M G-63$ Cells, Due to Early Induction of $G_{2} / M$}

We investigated the mechanisms induced by ionizing radiation on the internalization of NP-DOX in MG-63 cells using quantitative measurements of the atomic Fe concentration that were correlated with cell cycle measurements (Figure 5A). 

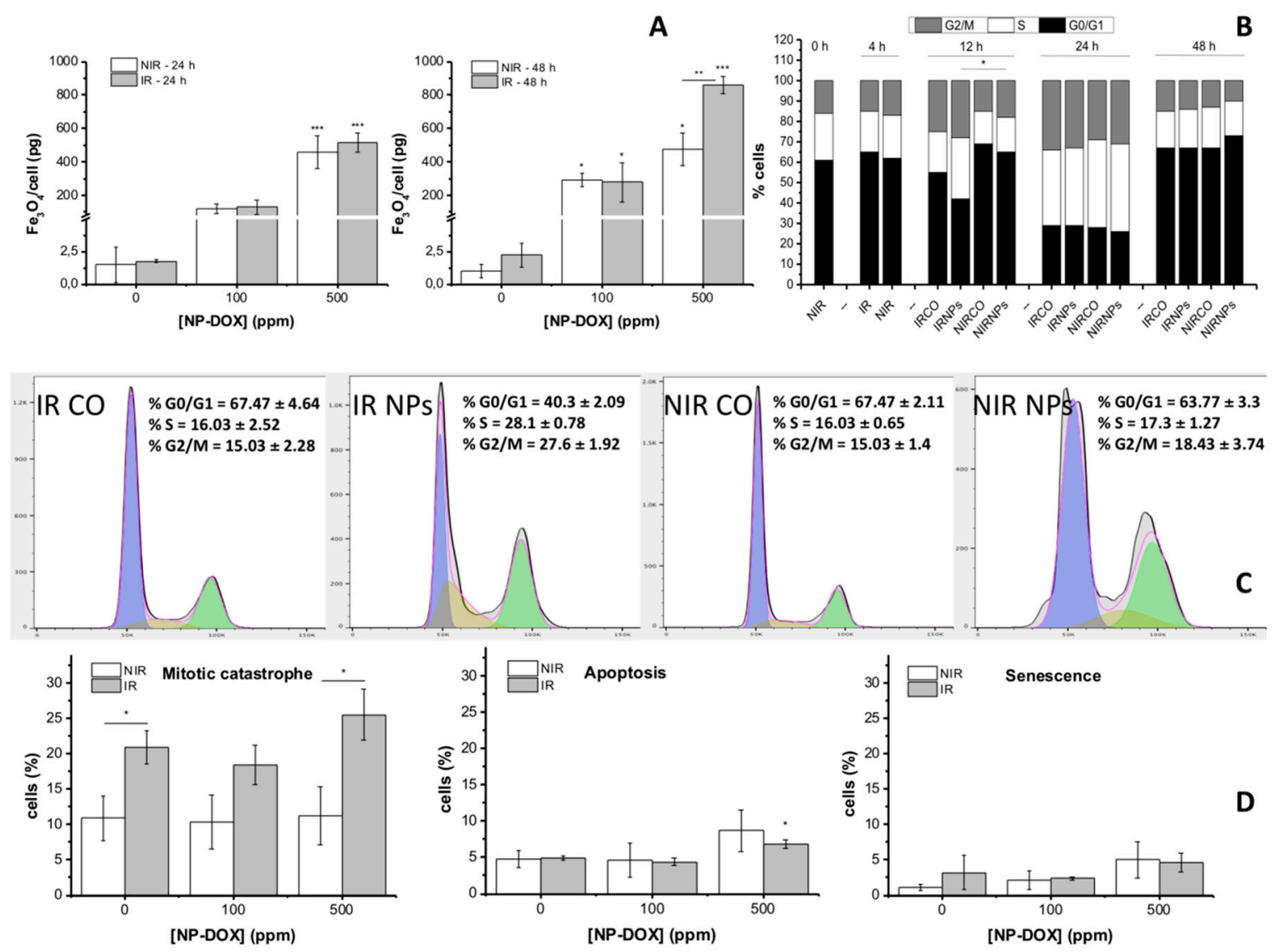

Figure 5. (A) Quantity of internalized NP-DOX in MG-63 cells exposed to different concentrations of NP-DOX for 24 and $48 \mathrm{~h}$. One group of cells was previously exposed to $1 \mathrm{~Gy}$ X-ray. Cell cycle distributions of MG-63 cells that were treated with and without X-ray irradiation ( 0 vs. $1 \mathrm{~Gy}$ ) and nanoparticles (0, 500 ppm NP-DOX) at (B) $12 \mathrm{~h}$ and (C) 0-48 h, respectively. (D) Cell death induced by 1 Gy X-rays, 100 ppm and/or 500 ppm, NP-DOX, in MG-63 cells. Cells were treated for $48 \mathrm{~h}$ and reseeded during $24 \mathrm{~h}$ for morphological evaluation and classification as apoptotic, multinuclear or senescent. Data are presented as mean $\pm \mathrm{SEM} ;{ }^{*} 0.01<p<0.05,{ }^{* *} 0.001<p<0.01,{ }^{* * *} p<0.001$.

The PIXE technique was used to measure the atomic concentration of Fe inside the MG-63 cells cultivated in the presence of NP-DOX for 24 and $48 \mathrm{~h}$, in groups previously exposed to different radiation doses ( 0 and 1 Gy) (Figure 5A). Results showed that exposure to NP-DOX induced an increase in atomic Fe concentration proportional to the fed nanoparticles concentration. Thus, after $24 \mathrm{~h}$ of exposure to $500 \mathrm{ppm} \mathrm{NP-DOX,} \mathrm{a} \mathrm{concentration} \mathrm{of} 458.61 \pm 97.12 \mathrm{pg} / \mathrm{cell}$ of $\mathrm{Fe}_{3} \mathrm{O}_{4}(p<0.001$, compared to control) was measured, while in the equivalent group that received prior radiation treatment, a higher concentration (517.3 $\pm 57.15 \mathrm{pg} / \mathrm{cell}, p<0.001$, compared to control) was determined. After $48 \mathrm{~h}$, a concentration of $473.5 \pm 97.63 \mathrm{pg} / \mathrm{cell}(p<0.05$, compared to control) internalized nanoparticles were measured for non-irradiated MG-63 cells exposed to $500 \mathrm{ppm}$ NP-DOX, and $860.15 \pm 52.36 \mathrm{pg} / \mathrm{cell}$ ( $p<0.001$, compared to control) nanoparticles for the group exposed to $1 \mathrm{~Gy} X$-ray and $500 \mathrm{ppm}$ NP-DOX, respectively. Thus, after $48 \mathrm{~h}$, the prior exposure to $1 \mathrm{~Gy}$ X-ray determined a statistically significant increase in the internalized amounts of nanoparticles in MG-63 cells for the highest given concentration (500 ppm), with $p<0.01$ compared to the equivalent non-irradiated group.

MG-63 cells were cultured until confluence to enhance the percent of cells in $G_{0} / G_{1}$ phase and afterwards received $1 \mathrm{~Gy} X$-ray treatment. Subsequent splitting and reseeding did not cause any statistically significant changes in the cell cycle distribution during $4 \mathrm{~h}$ of cultivation (Figure 5B,C). Twelve hours after radiation exposure, obvious changes in the cell cycle of the cells in each group were observed. 1 Gy X-ray treatment caused an accumulation of cells in $\mathrm{G}_{2} / \mathrm{M}$ after $12 \mathrm{~h}(24.8 \% \pm 2.3 \%$, 
$p<0.05$, compared to control cells), while nanoparticles alone did not cause a statistically significant effect. However, the group that received both radiation and NP-DOX treatment showed a significantly higher percent of cells accumulated in $\mathrm{G}_{2} / \mathrm{M}$ phase $(27.6 \pm 1.92, p<0.01$, compared to control cells, and $p<0.05$ compared to non-irradiated NP-DOX-treated cells). At $24 \mathrm{~h}$, about $30 \%$ of the cells underwent $\mathrm{G}_{2} / \mathrm{M}$ in all subjected groups (no statistically significant difference). At $48 \mathrm{~h}$, the percent of cells in $G_{2} / M$ was reduced in all groups (no statistically significant difference between the groups), showing that cells probably escaped $\mathrm{G}_{2} / \mathrm{M}$ blockage and entered mitosis.

\subsection{Cells Exit $G_{2} / M$ Arrest and Undergo Mitotic Catastrophe after Exposure to X-ray Irradiation and Subsequent NP-DOX Treatment}

The type of cell death after prior radiation and NP-DOX treatment of MG-63 cells was investigated through morphological determinations of the cell death (i.e., apoptosis, mitotic catastrophe, senescence).

The results (Figure 5D) showed that, after $48 \mathrm{~h}$ of NP-DOX treatment and another $24 \mathrm{~h}$ of resistant clones' sub-culturing, there is no additional statistically significant induction of apoptosis, for any of the subjected groups, with the exception of the group treated with $1 \mathrm{~Gy} X$-ray and $500 \mathrm{ppm}$ NP-DOX, where $6.8 \% \pm 0.06 \%$ of cells showed apoptotic alterations $(p<0.05$, compared to irradiated control). Irradiation alone determined an increase of 1.92-fold in cells showcasing multi-nuclei $(p<0.05$, compared to control), while for groups receiving only nanoparticles treatment, no statistically significant alteration in number of multi-nucleated cells was observed. On the contrary, for cells exposed to 1 Gy X-ray and 500 ppm NP-DOX, an increase of 2.34-fold was observed ( $p<0.01$, compared to non-irradiated control). The radiation treatment and nanoparticles seemed to contribute to the induction of a statistically significant increase of the mitotic catastrophe events for the highest NP-DOX concentration $(p<0.05)$. A small percent of senescent cells was observed in the populations exposed either to the highest concentration of nanoparticles or to the combined treatment.

Our results showed that MG-63 cells experience mitotic catastrophe in case of combined treatment (1 Gy of X-rays and NP-DOX). At $48 \mathrm{~h}$, cells undergoing both treatments were released from $\mathrm{G}_{2} / \mathrm{M}$ phase (low percent of cells in $\mathrm{G}_{2} / \mathrm{M}$, similar to control), with unrepaired DNA (high amount of DNA breaks) and aberrant mitosis (presence of multi-nucleated cells).

\section{Discussion}

In this report, we successfully proved that prior exposure to medium levels of ionizing radiation enhanced the internalization and the cytotoxicity of the novel synthesized nano-construct NP-DOX in aggressive MG-63 human osteosarcoma cells. Firstly, we designed, synthesized and characterized the nano-system (Supplementary Information Sections S1.1 and S2.1). Further, we demonstrated an efficient uptake of NP-DOX through macropinocytosis and transport in the peri-nuclear area. The MG-63 cells' treatment with the DOX-loaded nanoparticles led to a significant decrease in cells' proliferation, while the genotoxicity increased (Supplementary Information, Section S2.2). Next, we tested and showed that the combined ionizing radiation-nanoparticles (1 Gy irradiation applied prior to NP-DOX) treatment is more efficient in the induction of a cytotoxic anti-proliferative effect in osteosarcoma cells compared to nanoparticles alone. Mechanistic insights concerning the effect of ionizing radiation on the internalization and cytotoxicity of NP-DOX in the MG-63 osteosarcoma cells were revealed. A significantly higher percent of DOX-conjugated nanoparticles in the cells previously exposed to $1 \mathrm{~Gy} \mathrm{X}$-ray compared to other groups was found. This was accompanied by a premature entry of the MG-63 cells in $\mathrm{G}_{2} / \mathrm{M}$ phase. However, cells re-entered in $\mathrm{G}_{1}$ at $48 \mathrm{~h}$ after treatment (similar to untreated cells) and underwent mitotic catastrophe.

The bare iron oxide nanoparticles have been synthesized (Supplementary Information, Section S1.1) using a modified chemical co-precipitation method, as in Popescu et al. [18], which implied a 1.65:1 $\mathrm{Fe}^{3+}: \mathrm{Fe}^{2+}$ ratio, in order to compensate the oxidation of $\mathrm{Fe}^{2+}[20,21]$. The biocompatibility of bare $\mathrm{Fe}_{3} \mathrm{O}_{4}$ nanoparticles (NP) was proven by our in vitro data on cyto- and geno-toxicity (Supplementary Information, Section S2.2 and Figure 2H), confirming other reports [7]. 
The conjugation of doxorubicin with the $\mathrm{Fe}_{3} \mathrm{O}_{4}$ nanoparticles (NP-DOX) was done using an in situ functionalizing method, as the organic phase was introduced into the reaction system directly into the precipitation medium and was present during the nucleation of the nanoparticles. This allowed a direct interaction between the chemotherapeutic substance and the bare NP. It has been previously reported that doxorubicin can form complexes with $\mathrm{Fe}$, by means of the hydroquinone moieties, resulting in strong linking of the chemotherapeutic to iron [22]. Our data confirms that a stable interaction of the organic and inorganic phases was established. Nevertheless, the presence of the organic phase was confirmed through thermogravimetric analysis, as a difference of weight loss during heating of NP-DOX compared to non-conjugated NP (Supplementary Information, Section S2.1), but also through the prolonged fluorescence of the nano-constructs, as evidenced due to doxorubicin intrinsic fluorescence (Figure 2J).

Our investigations through fluorescence microscopy showed that conjugated nanoparticles are distributed in the cytoplasm of the MG-63 cells, most probably in endosome structures, while free doxorubicin directly went into the nucleus of the cells, due to a passive diffusion transport [23]. The mechanism of internalizing for NP-DOX is different and takes place more slowly. Thus, after $48 \mathrm{~h}$ of incubation, doxorubicin-conjugated nanoparticles are located in the vicinity of the nucleus. Kamba et al. have observed that $\mathrm{CaCO}_{3}$ /doxorubicin nanoparticles were predominantly spread in the cytoplasm of the MG-63 osteosarcoma cells, compared to free doxorubicin, which directly diffused into the nucleus of the cells [24], with the effect being attributed to the trapping of the constructs into the endosome compartment of the cells.

A possible mechanism of internalizing is macropinocytosis, as suggested by SEM investigations, emphasized through the "ruffling" aspect of the cellular membrane, but also the presence of macropinosomes (Figures 1 and 2C,D) [25,26]. Moreover, the extracellular fibrils network matches the description of the Candida glabrata internalizing in MG-63 cells and imaging of Gd nanoparticles macropinocytosis in head and neck squamous cell carcinoma cells (SQ20B) [27]. As macropinocytosis is directly related to actin cytoskeleton dynamics, information on actin filaments' organization was correlated with high-resolution SEM morphology observations. At $24 \mathrm{~h}$ after treatment, the fibrils actin network underwent morphological alterations matching the description of micropinocytosis-specific "ruffling" (Figures 1 and 2C,D) [26-28]. However, at $48 \mathrm{~h}$ after treatment, there was less structure in the actin network and the cytoplasm seemed to have lost its integrity (Figure 2). This might be due to DOX release leading to actin filaments' depolymerisation (Figure 2I,J,L), as bare NP did not cause any alteration of the actin filaments' structure (Figure 2H) [29,30].

Further we have used medium-dose X-ray (1 Gy) to sensitize confluent MG-63 osteosarcoma cells for the newly developed doxorubicin-conjugated iron oxide nanoparticles. We showed that combined treatment enhanced the cytotoxic and genotoxic effects in osteosarcoma cells compared to nanoparticles alone (Figures 3 and 4). Our data also showed that $\mathrm{G}_{2} / \mathrm{M}$ temporary cell cycle arrest in MG-63 cells exposed to combined treatment (1 Gy X-ray +500 ppm nanoparticles) was linked to an enhanced internalization of NP-DOX (Figure 5). The group of cells receiving $1 \mathrm{~Gy}$ and $500 \mathrm{ppm}$ nanoparticles showed an early induction of $\mathrm{G}_{2} / \mathrm{M}$ arrest at $12 \mathrm{~h}$ that reached a maximum at $24 \mathrm{~h}$ after treatment, when all groups underwent $\mathrm{G}_{2} / \mathrm{M}$ arrest (Figure $5 \mathrm{~B}, \mathrm{C}$ ). A comparable prolonged effect of $\mathrm{G}_{2} / \mathrm{M}$ cell cycle arrest was reported for HeLa Hep2 cells exposed to $2.5 \mathrm{~Gy}$ (60 MeV, $0.45 \mathrm{~Gy} / \mathrm{min}$ ) [31]. More recently, other similar results have been reported by Yi et al., who have shown that CuS@Melanin/polyethylene glycol PEG-DOX-loaded nanoparticles might have good potential in the nanoparticles-mediated chemo-radiotherapy, proving both a radio-sensitizing effect in post-internalization radiotherapy or enhanced uptake in previously irradiated cells [17]. Liu et al. [13] have also observed that a previous exposure of HeLa cells to ionizing radiation can lead to an enhanced quantity of gold nanoparticles to be internalized, an effect linked to a higher percent of cells undergoing cell cycle arrest in $G_{2} / M$ following X-ray exposure.

It is well known that ionizing radiation causes a cell cycle arrest, determining cells to have a non-reproductive state [32]. On the other hand, the internalized agent itself can cause an effect, 
leading to a $G_{2} / M$ arrest and, thus, to its enhanced uptake by the cell, with some examples of such events being the formation of reactive oxygen species [33] or cell cycle interfering drug release (e.g., doxorubicin [34], docetaxel [35]). In our case, during the first $24 \mathrm{~h}$ of exposure, more than $60 \%$ of DOX is released from the nanoparticles. Although it is known for DOX to cause $G_{2} / M$ arrest in MG-63 cells [36], the released amount during this period of time from the internalized nanoparticles might be too small to cause a significant alteration of $\mathrm{G}_{2} / \mathrm{M}$ on its own.

Previously, it has been stated by many groups that cells' uptake is strongly influenced by their cell cycle phase [37-40]. A significant difference in internalizing among cells in different phases of the cell cycle can be noticed after $24 \mathrm{~h}$ (mostly one complete cell cycle for most types of immortalized cells) $[33,38]$. Taking this into consideration, cells that go through more or extended $\mathrm{G}_{2} / \mathrm{M}$ phases during a monitored time interval will exhibit a higher concentration of internalized nanoparticles [13].

Exposure to ionizing radiation ( $1 \mathrm{~Gy}$ ) prior to NP-DOX administration led to a significantly increased concentration of nanoparticles per cell in the $1 \mathrm{~Gy}+500 \mathrm{ppm}$ group, measured at $48 \mathrm{~h}$. Before this time point, the previously irradiated cells have been undergoing a prolonged $G_{2} / M$ phase, allowing more nanoparticles to be internalized. A higher ability of nanoparticles' uptake in an osteosarcoma tumor model was also proven in vivo for liposomal doxorubicin (Caelyx, $8 \mathrm{mg} / \mathrm{kg}$ dose) [41]. Caelyx was intravenously administered one day before irradiation (single dose 8 Gy or fractionated doses of 3.6 Gy for 3 days, $6 \mathrm{MV}$ X-rays), leading to an improved penetration of DOX inside the osteosarcoma in irradiated subjects.

At $48 \mathrm{~h}$ (when all cells exit $\mathrm{G}_{2} / \mathrm{M}$ ), a significant increase in chromosomal damage was observed for the $1 \mathrm{~Gy}+500$ ppm NP-DOX group, compared to the 500 ppm group, while there were small differences in inhibition of proliferation between the two groups. Long-term monitoring (clonogenic assay) showed that previous radiation induced a statistically significant reduction of the survival rate for cells receiving NP-DOX treatment. However, the combined treatment effect is additive rather than synergic since the sum of the effects of each factor is a bit higher than the combined effect (Figure 3C).

Many cancer cells, including MG-63, exhibit the inability of the cells to undergo apoptosis, resulting in continuous proliferation, even if their DNA was damaged [42,43]. Syljuasen et al. [44] have proved that in human osteosarcoma cells, a $\mathrm{G}_{2}$ checkpoint arrest occurs, induced by exposure to ionizing radiation, correlated with DNA breaks (measured by gamma H2AX assay); however, the cells are able to exit this temporary arrest and undergo mitosis at around $30 \mathrm{~h}$ from radiation treatment, while still expressing the markers for unrepaired DNA double-strand breaks. Our results show that all cells exit from $\mathrm{G}_{2} / \mathrm{M}$ arrest until $48 \mathrm{~h}$, being in agreement with Syljuasen's report. In cells irradiated in $\mathrm{G}_{0} / \mathrm{G}_{1}$ and exiting $\mathrm{G}_{2} / \mathrm{M}$ arrest to enter mitosis, DNA double-strand breaks have duplicated and can be counted as micronuclei in $\mathrm{M}$ phase cells [45].

The ability of cells exhibiting DNA damage to enter mitosis without fulfilling DNA repair in $\mathrm{G}_{2}$ has been defined as mitotic catastrophe and described repeatedly $[46,47]$. The aberrant mitosis leads to either death or polyploidy, the cells eventually undergoing cell death, senescence or formation of single tetraploid cells [46,48]. After $48 \mathrm{~h}$ of treatment, classification of MG-63 cells by morphologic clonogenic assay showed that neither irradiation alone, nor nanoparticles alone, resulted in any statistically significant apoptotic death after induction of mitosis (Figure 5A). However, exposure to 500 ppm NP-DOX after 1 Gy X-rays showed a statistically significant increase in the population of apoptotic cells, compared to only irradiated cells. Polyploidy was shown to be determined by radiation treatment and enhanced by the addition of the highest concentration of NP-DOX. Additionally, the previously mentioned observations on actin network reorganization in MG-63 cells after $48 \mathrm{~h}$ of treatment matches older descriptions on actin filaments' reorganization and implication in mitotic catastrophe cell death [49-51]. It is for the first time that the mitotic catastrophe was correlated with an increased accumulation of nanoparticles after exposure to ionizing radiation.

Furthermore, the hemocompatibility evaluation and in vivo biodistribution studies emphasized that the NP-DOX did not cause any systemic response, nor organ cytotoxicity (Supplementary 
Material, Sections 2.3 and 2.4), which encourage further exploitation of these nano-systems in tumor preclinical models.

\section{Materials and Methods}

\subsection{Materials}

NP and NP-DOX nanoparticles were obtained using a modified chemical co-precipitation method, as in Popescu et al. [18]. A detailed description of nanoparticles' synthesis process and characterization is presented in Supplementary Information Sections S1.1 and S2.1.

\subsection{Cell Culture}

MG-63 human osteosarcoma cell line purchased from ATCC ${ }^{\circledR}$ was used as in vitro tumor model for the nano-constructs' cytotoxicity assessment. The cells were cultured in MEM Earle's (MEM) (Biochrom, Merck Milipore, Darmstadt, Germany), supplemented with 10\% fetal bovine serum (Biochrom, Merck Milipore), 1\% L-glutamine (Biochrom, Merck Milipore), 1\% non-essential amino-acids (Sigma Aldrich Germany) and $1 \%$ antibiotics (penicillin and streptomycin) (Biochrom, Merck Milipore). Cell cultures were maintained at $37^{\circ} \mathrm{C}$ in a humidified incubator ( $95 \%$ air, $5 \% \mathrm{CO}_{2}$ ).

\subsection{Cells Morphology, Cytoskeleton Evaluation and NP-DOX Internalization}

Scanning electron microscopy: SEM was performed in order to obtain information about the interaction of the nanoparticles with the cellular membrane. For this purpose, 50,000 cells were seeded on $24 \mathrm{~mm}$ diameter glass slides, placed in 6-well plates and cultured for $24 \mathrm{~h}$ under standard conditions, to allow attachment. The cells were treated with $1000 \mu \mathrm{L}$ of nanoparticle suspensions in complete culture medium at the concentration of $500 \mathrm{ppm}$, while in control wells (untreated cells), complete culture medium was added. The samples were incubated for another 14 and $48 \mathrm{~h}$, respectively. Then, the slides were washed with phosphate buffered saline(PBS), fixed in $2.5 \%$ glutaraldehyde for $1 \mathrm{~h}$ and were dehydrated in ethanol (EtOH) and hexamethyldisilasane (HMDS) solutions (EtOH in MiliQ 70\%, $90 \%$ and $100 \%$ for $30 \mathrm{~min}$; HMDS in $\mathrm{EtOH} 25 \%, 50 \%$ and 100\% for $3 \mathrm{~min}$ ). The samples were covered with a thin layer of Au and analyzed using a FEI SEM (Hillsboro, OR, USA) with a beam of secondary electrons having energies up to $30 \mathrm{keV}$.

Immunofluorescence: For the qualitative evaluation of the cytotoxic effects and nanoparticle internalization, we employed a multi-fluorescence labeling, enabling the cells' nucleus, cytoskeleton and the nanoparticles' localization. For the nanoparticles' localization, the fluorescent properties of doxorubicin have been exploited. The cell seeding and nanoparticles treatment was done similar as for SEM. To prepare the slides for fluorescence microscopy, the medium with nanoparticles was removed from the wells and the cells were gently washed with PBS 3 times. Then, $3.7 \%$ paraformaldehyde solution was used for fixing, during $10 \mathrm{~min}$. Next, the cells were permeabilized with $1 \%$ tryton $\mathrm{X}$ for $10 \mathrm{~min}$ and stained with fluorescein-5-isothiocyanate(FITC)-Phalloidin for $40 \mathrm{~min}$ and Hoechst for $10 \mathrm{~min}$ (in dark). The cells were gently washed with PBS after each step. The visualization of the prepared samples was done using an Olympus IX71 fluorescence microscope (Tokyo, Japan) and the image recording was done using an $\mathrm{iXON}^{\mathrm{EM}}+\mathrm{DU}-897$ camera (Andor Technology, Belfast, UK). Appropriate filter sets were used to record separate images for nuclei (blue), actin filaments (green), DOX and NP-DOX (red), in the same area. The images were merged using ImageJ (National Institutes of Health, Bethesda, MD, USA).

\subsection{Irradiation}

250,000 MG-63 cells were seeded into T25 flasks and incubated in standard conditions of temperature and humidity until they reached confluence. The cell culture medium was replaced with fresh medium and the cells were exposed to a dose of $1.085 \mathrm{~Gy}$ X-rays, at a debit of $2.394 \mathrm{mGy} / \mathrm{s}$, during $8 \mathrm{~min}$. For the generation of X-rays, an XStrahl XRC 160 (Surrey, UK) source was used (energy 
of $150 \mathrm{keV}$, current of $20 \mathrm{~mA}$ ). $30 \mathrm{~min}$ after radiation, cells were detached and reseeded as described below. The cells were allowed to attach for $4 \mathrm{~h}$; afterwards, the medium was replaced with fresh medium containing nanoparticles (concentrations of $0,10,100,500 \mathrm{ppm}$ ) and incubated in standard conditions of temperature and humidity during different time intervals $(24,48$ or $72 \mathrm{~h}$, according to the assays described below).

\subsection{Cytotoxicity and Proliferation Measurements}

The quantitative evaluation of the cytotoxic effect of the nanoparticles was done using the tetrazolium-salt (MTT)-based viability assay, according to Mosmann et al. and Denizot et al. [52,53]. After undergoing radiation treatment, the cells were re-seeded at a concentration of 4000 cells/well in 96-well plates and allowed attachment for $4 \mathrm{~h}$. The nanoparticle treatment was added at this time and the viability measurements were done at 24,48 and $72 \mathrm{~h}$ after the treatment. The absorbance at $570 \mathrm{~nm}$ was determined using a Mithras LB 940 (Berthold Technologies) microplate reader.

Trypan blue staining was used to evaluate the percent of dead cells or proliferation after subsequent nanoparticles exposure. The cells that underwent radiation were re-seeded at a concentration of $500,000 /$ well and incubated during $4 \mathrm{~h}$. Afterwards, the nanoparticles were added (concentrations of $100 \mathrm{ppm}$ and $500 \mathrm{ppm}$ NP-DOX) and incubated for different time intervals (12, 24, $48 \mathrm{~h})$. At the specified timepoints, the cells were washed with PBS and detached using $0.1 \%$ trypsin, which was then inactivated using 1:3 complete MEM. A volume of the cells' suspension was mixed with equal volume of trypan blue and cells were counted using a hemocytometer.

Clonogenic assay: The cells that underwent irradiation treatment were re-seeded and treated as for Trypan blue staining. After $48 \mathrm{~h}$ incubation with nanoparticle treatment, cells were harvested and counted. 300 cells/well from each group were seeded into 6-well plates in $2 \mathrm{~mL}$ and cultured for 14 days. After this time, the samples were gently washed with PBS and fixed with $3.7 \%$ paraformaldehyde (PFA) during $10 \mathrm{~min}$. Then, the cells were stained using a $0.5 \%$ Giemsa solution and colonies comprising at least 50 cells were counted.

Genotoxicity assessment: The chromosomal damage was assessed using the micronucleus assay [54,55]. After undergoing radiation treatment, 30,000 cells $/ 25 \mathrm{~mm}$ slide were seeded and allowed attachment for several hours. Solutions of NP-DOX in different concentrations were added $(0,100$ and $500 \mathrm{ppm}$ ) and incubated for an additional 48 or $72 \mathrm{~h}$. Cytochalasin B was added, and cells were incubated for an additional 18h. The slides were fixed using a 1:9 acetic acid:methanol solution and the DNA was stained using acridine orange $(10 \mu \mathrm{g} / \mathrm{mL}$ final concentration). The counting was done as previously reported [55].

The comet assay was used to measure the DNA breaks after radiation and/or NP-DOX treatment. Irradiated MG-63 cells were re-seeded and treated as for the clonogenic assay. The samples were harvested after $48 \mathrm{~h}$ of NP exposure. The comet assay was done in alkaline conditions, similarly to the procedure described by Singh et al. [56]. The cells were suspended in complete culture medium, mixed with 1\% low melting point agarose (Sigma Aldrich) and the suspension was layered on the surface of the slides previously covered with 1\% normal melting agarose (Sigma Aldrich). The slides were immediately covered with cover slips and incubated for $5 \mathrm{~min}$ on ice to allow the solidification of the agarose. The cover slips were removed, and cold lysis was performed using a $2.5 \mathrm{M} \mathrm{NaCl}$, $100 \mathrm{mM}$ ethylenediaminetetraacetic acid EDTA, $10 \mathrm{mM}$ Tris $(\mathrm{pH}=10)$, dimethyl sulfoxide DMSO and $1 \%$ tryton $\mathrm{X}-100$ for $1 \mathrm{~h}$ at $4{ }^{\circ} \mathrm{C}$. Then, the DNA electrophoresis was performed for $25 \mathrm{~min}$, using an alkaline electrophoresis solution $\left(300 \mathrm{mM} \mathrm{NaOH}, 1 \mathrm{mM}\right.$ EDTA, $\mathrm{pH}=13$, at $\left.4{ }^{\circ} \mathrm{C}\right)$. Then, the DNA was neutralized using a $0.4 \mathrm{M}$ Tris solution, at $\mathrm{pH}=7.5$. The DNA was stained using $70 \mu \mathrm{L}$ ethidium bromide $20 \mu \mathrm{g} / \mathrm{mL}$, washed with deionized water and covered with cover slips. Analysis of comet images was performed using the software Comet Assay IV, Perceptive Instruments, UK, and the fluorescence microscope Olympus (BX51), Olympus Optical Co., Tokyo, Japan, equipped with a Marlin F-046 CC digital camera. 
Morphological evaluation of cell death (Mitotic catastrophe, apoptosis and senescence evaluation): The samples were seeded and treated as for the clonogenic assay. After $48 \mathrm{~h}$ of interaction with NP-DOX, 10,000 cells/25 mm glass slide were seeded and cultured for an additional $24 \mathrm{~h}$. The cells were fixed using 1:9 solution of acetic acid:methanol and stained using acridin orange. In order to evaluate the clonogenic cell death, the cells were counted and grouped into normal, apoptotic, undergoing mitotic catastrophe or senescence according to Kobayashi et al. [57].

\subsection{Quantitative Cellular Internalizing Using Particle-Induced X-ray Emission}

Cells that underwent radiation treatment were detached and reseeded $(500,000$ cells/well). The nanoparticle treatment was done as for the clonogenic assay. After 24 and $48 \mathrm{~h}$ respectively, of incubation in the presence of nanoparticles, the cells were gently washed with PBS 3 times, for 5 min, in order to remove all the non-internalized NP. Afterwards, they were detached using $1 \%$ trypsin and fixed using 2.5\% glutaraldehyde. The samples were carefully deposited on a $1 \mu \mathrm{m}$ thick Mylar foil that was glued on an aluminum frame and allowed to dry.

PIXE analysis was performed at the 3 MV TandetronTM accelerator from "Horia Hulubei" National Institute for Physics and Nuclear Engineering (IFIN-HH), using a $2.7 \mathrm{MeV}$ proton beam and the in-air irradiation setup [58]. The characteristic X-rays were recorded by a silicon drift detector positioned at $45^{\circ}$ with respect to the beam direction and the spectra were processed with the Gupixwin 2.2.4 software [59].

The concentration of nanoparticles was calculated by reporting the $\mathrm{Fe}_{3} \mathrm{O}_{4}$ values to the viable cell number obtained from trypan blue assay, at each corresponding timepoint.

\subsection{Cell Cycle Analysis}

The cells that underwent irradiation treatment were seeded and treated as for the clonogenic assay. $30 \mathrm{~min}$ prior to fixing, $10 \mu \mathrm{M}$ bromodeoxyuridine (BrdU) was added into each well. The samples were washed, detached and fixed at 0, 4, 12, 24 and $48 \mathrm{~h}$ after irradiation, as in Reference [60]. BrdU-labeled cells were fixed in $70 \%$ ice-cold ethanol at $-20{ }^{\circ} \mathrm{C}$ for at least $24 \mathrm{~h}$. The cells were treated with $2 \mathrm{~mol} / \mathrm{L} \mathrm{HCl} / 0.5 \%$ tryton X-100 for $30 \mathrm{~min}$, then washed in PBS/0.5\% bovine serum albumin (BSA) and incubated in $0.1 \mathrm{~mol} / \mathrm{L}$ sodium tetraborate for $2 \mathrm{~min}$. After an additional wash in PBS/0.5\% BSA, cells were incubated with monoclonal anti-BrdU antibody (1:300; BD Biosciences) for $30 \mathrm{~min}$. The cells were washed in PBS/0.5\% BSA and then incubated with a FITC-conjugated secondary antibody for $30 \mathrm{~min}$ (1:300; Merck). Finally, the cells were stained with $5 \mu \mathrm{g} / \mathrm{mL}$ propidium iodide and $50 \mu \mathrm{g} / \mathrm{mL}$ ribonuclease (RNase) in PBS for $30 \mathrm{~min}$. The assay was performed on the BD FACSLyric (BD Biosciences, Franklin Lakes, NJ, USA), and analyzed using FlowJo 10.5 software (BD).

\subsection{Statistics}

The values were presented as means \pm standard error of the mean (SEM). Data were analyzed statistically using one-way analysis of variance (ANOVA).

\section{Conclusions}

Novel doxorubicin-conjugated iron oxide nanoparticles NP-DOX were prepared to improve the internalization and cytotoxicity in aggressive osteosarcoma cells previously exposed to medium-dose ionizing radiation. Highly crystalline nanoparticles were successfully synthesized and efficiently internalized in MG-63 human osteosarcoma cells through macropinocytosis and transport in the peri-nuclear area, showing cytotoxic effects. Previous exposure to ionizing radiation determined an enhanced cytotoxic, anti-proliferative and genotoxic effect of NP-DOX. A significantly higher percent of DOX-conjugated nanoparticles in the cells previously exposed to radiation was accompanied by an early entry of the MG-63 cells in $\mathrm{G}_{2} / \mathrm{M}$ phase. Re-entering in $\mathrm{G}_{1}$ at $48 \mathrm{~h}$ after treatment (similar to untreated cells) was correlated with morphological observations considering the nuclear alteration of osteosarcoma cells undergoing mitotic catastrophe. The $\mathrm{G}_{2} / \mathrm{M}$ transition appears to be a specific target 
in the strategy of combining radiotherapy with NP-DOX to increase therapeutic efficacy while sparing side effects. This combination could be envisaged as a potential candidate for osteosarcoma treatment.

Supplementary Materials: Supplementary materials can be found at http://www.mdpi.com/1422-0067/21/19/ 7220/s1. Figure S1 SEM for (A) $\mathrm{Fe}_{3} \mathrm{O}_{4}$ and (B) NP-DOX nanoparticles; Figure S2 TEM (A,E), HR-TEM (B,F) and SAED $(C, G)$ for NP $(A-C)$, respectively for NP-DOX (E-G); (D) release kinetics of doxorubicin from NP-DOX; data are presented as mean \pm SEM; $(\mathrm{H})$ XRD pattern for (non-) conjugated magnetite; the pattern has peaks characteristic for magnetite (JCPDS number 19-0629) at $18.31^{\circ}(111), 30.33^{\circ}(220), 35.51^{\circ}(311), 43.16^{\circ}(440), 53.61^{\circ}$ (422), $57.17^{\circ}$ (511); red-diffraction pattern for NP and blue- diffraction pattern for NP-DOX; Figure S3 Proliferation of MG-63 osteosarcoma cells exposed to NP and NP-DOX in equivalent concentrations for 24, 48 and $72 \mathrm{~h}$; the data were presented as mean \pm SEM; ${ }^{*} p<0.05$; Figure S4 Morphological apoptosis assay measurements for MG-63 osteosarcoma cells exposed to different concentrations of NP-DOX for 24 h; Figure S5 DNA breaks induction (alkaline comet assay) in MG-63 osteosarcoma cells exposed for $48 \mathrm{~h}$ to NP or NP-DOX; the data were presented as mean \pm SEM; ${ }^{*} p<0.05$; Figure S6 Transversal section through samples collected at 7 days from mice injected with NP-DOX: (a) brain; (b) liver; (c) myocardium; (d) pancreas; (e) lungs; (f) kidneys; hematoxilin-eosin staining (400X magnification; measure bar of $50 \mu \mathrm{m}$ ); Figure S7 Transversal section through spleen collected at 7 days from mice injected with NP-DOX; hematoxilin-eosin staining, magnification: (a) 100× (measure bar of $100 \mu \mathrm{m}$ ); (b) 200× (measure bar of $50 \mu \mathrm{m}$ ); (c) 400× (measure bar of $25 \mu \mathrm{m}$ ); (d) 1000× (measure bar of $25 \mu \mathrm{m}$ ); Figure S8 Transversal section through samples collected at 14 days from mice injected with NP-DOX: (a) brain; (b) liver; (c) myocardium; (d) pancreas (200x; measure bar $100 \mu \mathrm{m})$; (e) lungs; (f) kidneys; hematoxilin-eosin staining (400× magnification; measure bar of $50 \mu \mathrm{m}$ ); Figure S9 Transversal section through spleen collected at 14 days from mice injected with NP-DOX; hematoxilin-eosin staining, magnification: (a) 200× (measure bar of $50 \mu \mathrm{m}$ ); (b) 400× (measure bar of $25 \mu \mathrm{m}$ ); (c,d) 1000x (measure bar of $25 \mu \mathrm{m}$ ); Table S1 DLS and zeta potential measurements for NP-DOX.

Author Contributions: R.C.P. and D.I.S. conceived and designed the experiments; R.C.P. designed and synthesized the nanoparticles; R.T., B.S.V., A.B. and R.C.P. performed the characterization of the nanoparticles; R.C.P., C.M. and M.T. performed the in vitro testing and characterization; L.M. and G.D.M. performed the in vivo testing; C.C. prepared and tested the irradiation setup; M.S., D.M. and R.F.A. performed the PIXE measurements and data processing; R.C.P., M.R., D.I.S. and M.R.V. analyzed the data; M.R. performed the statistical analysis; R.C.P., D.I.S., M.R. and M.R.V. drafted the manuscript; D.I.S., M.R.V., M.R. and E.A. participated in the coordination. All authors have read and agreed to the published version of the manuscript.

Funding: This research was funded by Romanian Ministry of Education and Research, grants numbers PN 18090202/2018, PN 19060203/2019, Romanian Ministry of European Funds, grant number POSCCE-A2-O2.2.1-2013-1/Priority Axe 2, Project no 638/12.03.2014, ID 1970, SMIS-CSNR code 48652 and DEUTSCHERAKADEMISCHER AUSTAUSCHDIENST (DAAD), grant number 57299291. The APC was funded by Romanian Ministry of Education and Research, grant number 36 PFE/2018. PIXE experiments were done at IFIN-HH, using the 3 MV Tandetron accelerator, which is supported by the Romanian Ministry of Education and Research from the research facilities of national interest funds.

Acknowledgments: The synthesis and characterization of the nanoparticles were done at UPB, for which we would like to thank Alexandru Mihai Grumezescu and Georgeta Voicu for valuable information and support. We would like to thank Ana Pantelică and Andrei Apostol from IFIN-HH, who offered valuable information regarding the PIXE technique. The cell cycle measurements were done at UMM, for which we would like to thank Tech. Miriam Bierbaum and Tech. Adriana Grbenicek, for assistance.

Conflicts of Interest: The authors declare no conflict of interest.

\section{References}

1. WHO. Osteosarcoma-Review of CancerMedicines on the WHO List of Essential Medicines, Union for International Cancer Control WHO. Available online: https://www.who.int/selection_medicines/committees/ expert/20/applications/Osteosarcoma.pdf?ua=1 (accessed on 19 August 2020).

2. Janeway, A.K.; Maki, R. Chemotherapy and Radiation Therapy in the Management of Osteosarcoma. Available online: https:/www.uptodate.com/contents/chemotherapy-and-radiation-therapy-in-the-management-ofosteosarcoma (accessed on 19 August 2020).

3. Ando, K.; Heymann, M.-F.; Stresing, V.; Mori, K.; Rédini, F.; Heymann, D. Current therapeutic strategies and novel approaches in osteosarcoma. Cancers 2013, 5, 591-616. [CrossRef] [PubMed]

4. Carina, V.; Costa, V.; Sartori, M.; Bellavia, D.; De Luca, A.; Raimondi, L.; Fini, M.; Giavaresi, G. Adjuvant biophysical therapies in osteosarcoma. Cancers 2019, 11, 348. [CrossRef] [PubMed]

5. Ud-Din, F.; Aman, W.; Ullah, I.; Qureshi, O.S.; Mustapha, O.; Shafique, S.; Zeb, A. Effective use of nanocarriers as drug delivery systems for the treatment of selected tumors. Int. J. Nanomed. 2017, 12, 7291-7309. [CrossRef]

6. Xin, Y.; Yin, M.; Zhao, L.; Meng, F.; Luo, L. Recent progress on nanoparticle-based drug delivery systems for cancer therapy. Cancer Boil. Med. 2017, 14, 228. [CrossRef] [PubMed] 
7. Gobbo, O.L.; Sjaastad, K.; Radomski, M.W.; Volkov, Y.; Prina-Mello, A. Magnetic nanoparticles in cancer theranostics. Theranostics 2015, 5, 1249-1263. [CrossRef] [PubMed]

8. Wu, C.-Y.; Chen, Y.-C. Riboflavin immobilized Fe3O4 magnetic nanoparticles carried with n-butylidenephthalide as targeting-based anticancer agents. Artif. Cells Nanomed. Biotechnol. 2019, 47, 210-220. [CrossRef]

9. Chiang, M.-Y.; Lin, Y.-Z.; Chang, S.-J.; Shyu, W.-C.; Lu, H.-E.; Chen, S.-Y. Direct reprogramming of human suspension cells into mesodermal cell lineages via combined magnetic targeting and photothermal stimulation by magnetic graphene oxide complexes. Small 2017, 13, 1700703. [CrossRef]

10. MagForce. Fighting Cancer with Nanomedicine. Available online: http://www.magforce.de/en/home.html (accessed on 19 August 2020).

11. Yameen, B.; Choi, W.I.; Vilos, C.; Swami, A.; Shi, J.; Farokhzad, O.C. Insight into nanoparticle cellular uptake and intracellular targeting. J. Control. Release 2014, 190, 485-499. [CrossRef] [PubMed]

12. Kim, J.A.; Åberg, C.; De Cárcer, G.; Malumbres, M.; Salvati, A.; Dawson, K. Low dose of amino-modified nanoparticles induces cell cycle arrest. ACS Nano 2013, 7, 7483-7494. [CrossRef] [PubMed]

13. Liu, Y.; Chen, W.; Zhang, P.; Jin, X.; Liu, X.; Li, P.; Li, F.; Zhang, H.; Zou, G.; Li, Q. Dynamically-enhanced retention of gold nanoclusters in HeLa cells following X-rays exposure: A cell cycle phase-dependent targeting approach. Radiother. Oncol. 2016, 119, 544-551. [CrossRef]

14. Panzarini, E.; Mariano, S.; Vergallo, C.; Carata, E.; Fimia, G.M.; Mura, F.; Rossi, M.; Vergaro, V.; Ciccarella, G.; Corazzari, M.; et al. Glucose capped silver nanoparticles induce cell cycle arrest in HeLa cells. Toxicol. In Vitro 2017, 41, 64-74. [CrossRef] [PubMed]

15. Martínez-Torres, A.C.; Zárate-Triviño, D.; Lorenzo-Anota, H.Y.; Ávila-Ávila, A.; Rodríguez-Abrego, C.; Rodríguez-Padilla, C. Chitosan gold nanoparticles induce cell death in HeLa and MCF-7 cells through reactive oxygen species production. Int. J. Nanomed. 2018, 13, 3235-3250. [CrossRef]

16. Yang, S.; Xing, L.; Gu, L.; Cheng, H.; Feng, Y.; Zhang, Y. Combination of RIZ1 overexpression and radiotherapy contributes to apoptosis and DNA damage of HeLa and SiHa cervical cancer cells. Basic Clin. Pharmacol. Toxicol. 2018, 123, 137-146. [CrossRef] [PubMed]

17. Yi, X.; Chen, L.; Chen, J.; Maiti, D.; Chai, Z.; Liu, Z.; Yang, K. Biomimetic copper sulfide for chemo-radiotherapy: Enhanced uptake and reduced efflux of nanoparticles for tumor cells under ionizing radiation. Adv. Funct. Mater. 2017, 28, 1705161. [CrossRef]

18. Popescu, R.C.; Andronescu, E.; Vasile, B.; Trusca, R.; Bragaru, A.; Mogoantă, L.; Mogosanu, G.D.; Temelie, M.; Radu, M.; Grumezescu, A.M.; et al. Fabrication and cytotoxicity of gemcitabine-functionalized magnetite nanoparticles. Molecules 2017, 22, 1080. [CrossRef]

19. Johansson, S.A.E.; Campbell, J.L.; Malmqvist, K.G. Particle-Induced X-ray Emission Spectrometry (PIXE); Wiley: New York, NY, USA, 1995.

20. Maity, D.; Agrawal, D. Synthesis of iron oxide nanoparticles under oxidizing environment and their stabilization in aqueous and non-aqueous media. J. Magn. Magn. Mater. 2007, 308, 46-55. [CrossRef]

21. Jiang, W.; Lai, L.L.; Hu, H.; Zeng, X.B.; Lan, F.; Liu, K.X.; Wu, Y.; Gu, Z.W. The effect of $\left[\mathrm{Fe}^{3+}\right] /\left[\mathrm{Fe}^{2+}\right] \mathrm{molar}^{2}$ ratio and iron salts concentration on the properties of superparamagnetic iron oxide nanoparticles in the water/ ethanol/ toluene system. J. Nanopart. Res. 2011, 13, 5135-5145. [CrossRef]

22. Hoskins, W.J.; Berchuck, A.; Markman, M.; Randall, M.E. Principle and Practice of Gynecologic Oncology; Lippincott Williams \& Wilkins: Philadelphia, PA, USA, 2005; p. 508.

23. Speelmans, G.; Staffhorst, R.W.H.M.; Steenbergen, H.G.; de Kruijff, B. Transport of the anti-cancer drug doxorubicin across cytoplasmatic membranes and membranes composed of phospholipids derived from Escherichia coli occurs via a similar mechanism. BBA Biomembr. 1996, 1284, 240-246. [CrossRef]

24. Kamba, S.A.; Ismail, M.; Hussein-Al-Ali, S.H.; Ibrahim, T.A.T.; Abu Bakar, Z. In Vitro delivery and controlled release of doxorubicin for targeting osteosarcoma bone cancer. Molecules 2013, 18, 10580-10598. [CrossRef]

25. Mercer, J.; Helenius, A. Virus entry by macropinocytosis. Nature 2009, 11, 510-520. [CrossRef]

26. Rima, W.; Sancey, L.; Aloy, M.-T.; Armandy, E.; Alcantara, G.B.; Epicier, T.; Malchère, A.; Joly-Pottuz, L.; Mowat, P.; Lux, F.; et al. Internalization pathways into cancer cells of gadolinium-based radiosensitizing nanoparticles. Biomaterials 2013, 34, 181-195. [CrossRef] [PubMed]

27. Muñoz-Duarte, A.R.; Castrejón-Jiménez, N.S.; Baltierra-Uribe, S.L.; Pérez-Rangel, S.J.; Carapia-Minero, N.; Castañeda-Sánchez, J.I.; Luna-Herrera, J.; López-Santiago, R.; Tovar, A.R.; García-Pérez, B.E. Candida glabrata survives and replicates in human osteoblasts. Pathog. Dis. 2016, 74, ftw030. [CrossRef] [PubMed] 
28. Bloomfield, G.; Kay, R.R. Uses and abuses of macropinocytosis. J. Cell Sci. 2016, 129, 2697-2705. [CrossRef] [PubMed]

29. Wei, L.; Surma, M.; Gough, G.; Shi, S.; Lambert-Cheatham, N.; Chang, J.; Shi, J. Dissecting the mechanisms of doxorubicin and oxidative stress-induced cytotoxicity: The involvement of Actin Cytoskeleton and ROCK1. PLoS ONE 2015, 10, e0131763. [CrossRef]

30. Grzanka, D.; Marszałek, A.; Gagat, M.; Izdebska, M.; Gackowska, L.; Grzanka, A. Doxorubicin-induced F-actin reorganization in cofilin-1 (nonmuscle) down-regulated CHO AA8 cells. Folia Histochem. Cytobiol. 2010, 48, 377-386. [CrossRef]

31. Eriksson, D.; Löfroth, P.-O.; Johansson, L.; Riklund, K.; Stigbrand, T. Cell cycle disturbances and mitotic catastrophes in HeLa Hep2 cells following 2.5 to $10 \mathrm{~Gy}$ of ionizing radiation. Clin. Cancer Res. 2007, 13, 5501s-5508s. [CrossRef]

32. Bernhard, E.J.; Maity, A.; Muschel, R.J.; McKenna, W.G. Effects of ionizing radiation on cell cycle progression. Radiat. Environ. Biophys. 1995, 34, 79-83. [CrossRef]

33. Patel, P.; Kansara, K.; Senapati, V.A.; Shanker, R.; Dhawan, A.; Kumar, A. Cell cycle dependent cellular uptake of zinc oxide nanoparticles in human epidermal cells. Mutagenesis 2016, 31, 481-490. [CrossRef]

34. Rajaram, R. Biocompatibility, uptake and anti-cancer activity of doxorubicin loaded gold nanoparticles in MCF-7 breast cancer cell line. Nanosci. Technol. Open Access 2016, 3, 1-10. [CrossRef]

35. Gao, H.; Hu, G.; Zhang, Q.; Zhang, S.; Jiang, X.; He, Q. Pretreatment with chemotherapeutics for enhanced nanoparticles accumulation in tumor: The potential role of G2 cycle retention effect. Sci. Rep. 2014, 4, 4492. [CrossRef]

36. Graat, H.C.A.; Witlox, M.A.; Schagen, F.H.E.; Kaspers, G.J.L.; Helder, M.N.; Bras, J.; Schaap, G.R.; Gerritsen, W.R.; Wuisman, P.I.J.M.; Van Beusechem, V.W. Different susceptibility of osteosarcoma cell lines and primary cells to treatment with oncolytic adenovirus and doxorubicin or cisplatin. Br. J. Cancer 2006, 94, 1837-1844. [CrossRef] [PubMed]

37. Zhou, Y.; Wang, H.; Tse, E.; Li, H.; Sun, H. Cell cycle-dependent uptake and cytotoxicity of arsenic-based drugs in single leukemia cells. Anal. Chem. 2018, 90, 10465-10471. [CrossRef] [PubMed]

38. Kim, J.A.; Åberg, C.; Salvati, A.; Dawson, K. Role of cell cycle on the cellular uptake and dilution of nanoparticles in a cell population. Nat. Nanotechnol. 2011, 7, 62-68. [CrossRef] [PubMed]

39. Tang, J.; Liu, Z.; Ji, F.; Li, Y.; Liu, J.; Song, J.; Li, J.; Zhou, J. The role of the cell cycle in the cellular uptake of folate-modified poly(l-amino acid) micelles in a cell population. Nanoscale 2015, 7, 20397-20404. [CrossRef] [PubMed]

40. Hu, G.; Cun, X.; Ruan, S.; Shi, K.; Wang, Y.; Kuang, Q.; Hu, C.; Xiao, W.; He, Q.; Gao, H. Utilizing G2/M retention effect to enhance tumor accumulation of active targeting nanoparticles. Sci. Rep. 2016, 6, 27669. [CrossRef]

41. Davies, C.D.L. Radiation improves the distribution and uptake of liposomal Doxorubicin (Caelyx) in human osteosarcoma xenografts. Cancer Res. 2004, 64, 547-553. [CrossRef]

42. Hu, X.; Yu, A.-X.; Qi, B.; Fu, T.; Wu, G.; Zhou, M.; Luo, J.; Xu, J.-H. The expression and significance of IDH1 and p53 in osteosarcoma. J. Exp. Clin. Cancer Res. 2010, 29, 43. [CrossRef]

43. Liu, P.; Wang, M.; Li, L.; Jin, T. Correlation between osteosarcoma and the expression of WWOX and p53. Oncol. Lett. 2017, 14, 4779-4783. [CrossRef]

44. Syljuåsen, R.G.; Jensen, S.; Bartek, J.J.; Lukas, J. Adaptation to the ionizing radiation-induced G2 checkpoint occurs in human cells and depends on checkpoint Kinase 1 and Polo-like Kinase 1 Kinases. Cancer Res. 2006, 66, 10253-10257. [CrossRef]

45. Deckbar, D.; Birraux, J.; Krempler, A.; Tchouandong, L.; Beucher, A.; Walker, S.; Stiff, T.; Jeggo, P.A.; Löbrich, M. Chromosome breakage after G2 checkpoint release. J. Cell Boil. 2007, 176, 749-755. [CrossRef]

46. Castedo, M.; Perfettini, J.-L.; Roumier, T.; Andréau, K.; Medema, R.; Kroemer, G. Cell death by mitotic catastrophe: A molecular definition. Oncogene 2004, 23, 2825-2837. [CrossRef]

47. Roninson, I.B.; Broude, E.V.; Chang, B.-D. If not apoptosis, then what? Treatment-induced senescence and mitotic catastrophe in tumor cells. Drug Resist. Updates 2001, 4, 303-313. [CrossRef] [PubMed]

48. Potapova, T.A.; Gorbsky, G.J. The consequences of chromosome segregation errors in mitosis and meiosis. Biology 2017, 6, 12. [CrossRef] [PubMed] 
49. Grzanka, D.; Izdebska, M.; Gackowska, L.; Stępień, A.; Marszalek, A. Actin reorganization in CHO AA8 cells undergoing mitotic catastrophe and apoptosis induced by doxorubicin. Oncol. Rep. 2010, 23, 655-663. [CrossRef]

50. Pawlik, A.; Nowak, J.M.; Grzanka, D.; Gackowska, L.; Michalkiewicz, J.; Grzanka, A. Hyperthermia induces cytoskeletal alterations and mitotic catastrophe in p53-deficient H1299 lung cancer cells. Acta Histochem. 2013, 115, 8-15. [CrossRef]

51. Grzanka, D.; Gagat, M.; Izdebska, M. Actin is required for cellular death. Acta Histochem. 2013, 115, 775-782. [CrossRef]

52. Mosmann, T. Rapid colorimetric assay for cellular growth and survival: Application to proliferation and cytotoxicity assays. J. Immunol. Methods 1983, 65, 55-63. [CrossRef]

53. Denizot, F.; Lang, R. Rapid colorimetric assay for cell growth and survival. Modifications to the tetrazolium dye procedure giving improved sensitivity and reliability. J. Immunol. Methods 1986, 89, 271-277. [CrossRef]

54. Fenech, M. The micronucleus assay determination of chromosomal level DNA damage. Breast Cancer 2008, 410, 185-216. [CrossRef]

55. Temelie, M.; Popescu, R.C.; Cocioaba, D.; Vasile, B.S.; Savu, D. Biocompatibility study of magnetite nanoparticle synthesized using a green method. Rom. J. Phys. 2018, 63, 703.

56. Singh, N.P.; McCoy, M.T.; Tice, R.R.; Schneider, E.L. A simple technique for quantitation of low levels of DNA damage in individual cells. Exp. Cell Res. 1988, 175, 184-191. [CrossRef]

57. Kobayashi, D.; Oike, T.; Shibata, A.; Niimi, A.; Kubota, Y.; Sakai, M.; Amornwhichet, N.; Yoshimoto, Y.; Hagiwara, Y.; Kimura, Y.; et al. Mitotic catastrophe is a putative mechanism underlying the weak correlation between sensitivity to carbon ions and cisplatin. Sci. Rep. 2017, 7, 40588. [CrossRef] [PubMed]

58. Burducea, I.; Straticiuc, M.; Ghita, D.G.; Mosu, D.V.; Calinescu, C.I.; Podaru, N.C.; Mous, D.J.W.; Ursu, I.; Zamfir, N.V. A new ion beam facility based on a 3MV TandetronTM at IFIN-HH, Romania. Nucl. Instrum. Methods Phys. Res. B 2015, 359, 12-19. [CrossRef]

59. Campbell, J.L.; Boyd, N.; Grassi, N.; Bonnick, P.; Maxwell, J. The Guelph PIXE software package IV. The Guelph PIXE software package IV. Nucl. Instrum. Methods Phys. Res. B 2010, 268, 3356-3363. [CrossRef]

60. Nicoletti, I.; Migliorati, G.; Pagliacci, M.; Grignani, F.; Riccardi, C. A rapid and simple method for measuring thymocyte apoptosis by propidium iodide staining and flow cytometry. J. Immunol. Methods 1991, 139, 271-279. [CrossRef] 